Short Communication

\title{
Synthesis of $0.4 \mathrm{Li}_{2} \mathrm{MnO}_{3} \cdot 0.6 \mathrm{LiNi}_{2 / 3} \mathrm{Mn}_{1 / 3} \mathrm{O}_{2} /$ graphene Nano- Composite Materials with Cross-Linked Structure and Enhanced Rate Performance for Lithium-Ion Batteries
}

\author{
Pengchang $\mathrm{Ma}^{*}$, Yong Hou \\ Zhongshan Polytechnic, Zhongshan 528400, PR China. \\ *E-mail: mpcmyc99@aliyun.com
}

doi: $10.20964 / 2018.11 .80$

Received: 12 March 2018 / Accepted: 16 May 2018 / Published: 1 October 2018

\begin{abstract}
Nano $0.4 \mathrm{Li}_{2} \mathrm{MnO}_{3} \cdot 0.6 \mathrm{LiNi}_{2 / 3} \mathrm{Mn}_{1 / 3} \mathrm{O}_{2} /$ graphene composites have been synthesized by a facile sol-gel method and temperature programmed calcination route. The as-obtained products exhibited a nice morphology which was nano-sized cross-linked structure. And it showed an excellent rate performance when it was used as cathode materials for lithium ion batteries. When it was at the current density of 2 $\mathrm{C}$, the discharge capacity could reach to $205 \mathrm{mAh} \mathrm{g}^{-1}$ for the first cycle and the capacity retention stayed over $97 \%$ after 100 cycles. The superior electrochemical behavior of $0.4 \mathrm{Li}_{2} \mathrm{MnO}_{3} \cdot 0.6 \mathrm{LiNi}_{2 / 3} \mathrm{Mn}_{1 / 3} \mathrm{O}_{2} /$ graphene nanocomposite materials could be ascribed to the unique nano-sized cross-linked structure, the maintaining of electrode integrity, the short diffusion distance, and continuously and rapidly electron conducting.
\end{abstract}

Keywords: $0.4 \mathrm{Li}_{2} \mathrm{MnO}_{3} \cdot 0.6 \mathrm{LiNi}_{2 / 3} \mathrm{Mn}_{1 / 3} \mathrm{O}_{2}$ /grapheme; microstructure; cross-linked structure; nanocomposite; cathode; lithium ion batteries.

\section{FULL TEXT}

(C) 2018 The Authors. Published by ESG (www.electrochemsci.org). This article is an open access article distributed under the terms and conditions of the Creative Commons Attribution license (http://creativecommons.org/licenses/by/4.0/). 